\title{
Analisa Resiko Postur Kerja Berdasarkan Hasil Evaluasi Menggunakan Metode Quick Exposure Check
}

\author{
Achmad Ganni Rizaldi ${ }^{1}$, Atikha Sidhi Cahyana ${ }^{2}$ \\ ${ }^{1,2}$ Program Studi Teknik Industri, Fakultas Sains dan Teknologi \\ Universitas Muhammadiyah Sidoarjo \\ Alamat Email : achmadganni96@gmail.com¹ , atikhasidhi@umsida.ac.id² $^{2}$
}

\begin{abstract}
ABSTRAK
UMKM XYZ merupakan industri bergerak dibidang pembuatan sepatu, produk yang menjadi unggulan adalah jenis sepatu bordir. Proses pengerjaan pembuatan sepatu bordir membutuhkan penanganan secara manual oleh pekerja sehingga pada proses produksinya masih terdapat serangkaian postur kerja yang tidak ergonomi. Metode penilaian postur kerja yang digunakan yaitu Quick Exposure Check (QEC). Metode QEC dipilih karena metode ini merupakan metode yang sederhana dan mudah untuk dipahami serta metode ini juga menilai dari dua sudut pandang, yaitu worker assessment dan observer assessment. Berdasarkan dari penelitian ini perhitungan kembali total exposure level dari usulan perbaikan fasilitas kerja, diharapkan mendapat nilai exposure level dengan range $<40 \%$. Nilai ini berarti stasiun kerja aman dan dapat menurunkan cidera musculocetal dan meningkatkan produktivitas pekerja.
\end{abstract}

Kata Kunci : Ergonomi, Quick Exposure Check, Postur Kerja, Produktivitas

\begin{abstract}
UMKM XYZ is an industry engaged in making shoes, the superior product is the type of embroidered shoes. The process of making embroidery shoes requires manual handling by workers so that in the production process there are still a series of non-ergonomic work postures. The work posture assessment method used is the Quick Exposure Check (QEC). The QEC method was chosen because this method is simple and easy to understand and this method also assesses from two points of view, namely worker assessment and observer assessment. Based on this research, the recalculation of the total exposure level of the proposed improvements to work facilities is expected to obtain an exposure level value with a range of $<40 \%$. This value means the work station is safe and can reduce musculocetal injuries and increase worker productivity.
\end{abstract}

Keywords : Ergonomics, Quick Exposure Check, Work Posture, Productivity

\section{PENDAHULUAN}

UMKM XYZ merupakan industri bergerak dibidang pembuatan sepatu, produk yang menjadi unggulan dari UMKM XYZ adalah jenis sepatu bordir. Pada proses pengerjaan pembuatan produk sepatu bordir ini beberapa tahapan kerja yang ada di UMKM ini merupakan pekerjaan yang dilakukan oleh manusia. Aktivitas pekerjaan manual yang dilakukan secara berulang-ulang dan dalam jangka waktu yang lama sering kali menimbulkan cidera Muscoluskeletal [1]. Untuk itu perlu dilakukan penilaian analisa resiko postur kerja dan perubahan posisi kerja yang bertujuan untuk mengurangi beban kerja dan menaggulangi cidera Muscoluskeletal dengan menggunakan metode Quick Exposure Check (QEC) [2]. Dari pengawasan yang dilakukan pemilik UMKM didapatkan nilai dari stasiun kerja yang ada berada pada range 50 - 69\%, sehingga perlu diberikan usulan perbaikan. Gangguan muskuloskeletal merupakan penyakit degeneratif, penyakit yang menyebabkan jaringan tubuh pekerja rusak secara lambat laun. Hal ini dapat mengakibatkan rasa sakit dan mengurangi kemampuan pekerja untuk bergerak, yang dapat mencegah pekerja dalam melakukan kegiatan sehari-hari [1].

Tujuan dari penelitian ini adalah untuk menganalisa resiko postur kerja. Quick Exposure Check merupakan suatu metode untuk penilaian terhadap resiko kerja yang berhubungan dengan gangguan otot ditempat kerja. Metode ini menilai gangguan resiko yang terjadi pada bagian belakang punggung, bahu, pergelangan tangan dan

Analisa Resiko Postur Kerja Berdasarkan Hasil Evaluasi Menggunakan Metode Quick Exposure Check / Achmad Ganni Rizaldi, Atikha Sidhi Cahyana

Peer reviewed under responsibili of Universitas Muhammadiyah Sidoarjo.

(C) 2021 Universitas Muhammadiyah Sidoarjo. All Right reserved. This is an open access article under the CC BY licence (http://creativecommons.org/licences/by/4.0/ ) 
leher [3]. Sedangkan Nordic Body Map memberikan hasil berupa keluhan pekerja terutama pada bagian leher, punggung, pantat, bahu, lengan, tangan dan pergelangan tangan [4].

Manfaat dari penelitian ini adalah untuk memperbaiki postur tubuh pada saat bekerja untuk mengurangi resiko kelelahan yang dialami pekerja. Dan diharapkan dengan adanya perubahan posisi kerja dapat mengurangi postur kerja yang tidak ergonomi dan meminimalisirkan gangguan sakit musculoskeletal, sehingga pekerja dapat bekerja tidak cepat lelah dan bekerja secara produktif.

\section{METODE}

Pada penelitian ini menggunakan metode quick exposure check untuk mengetahui resiko cidera pada otot rangka/sistem muskuloskeletal (muscoluskeletal disorder) yang menitikberatkan pada tubuh bagian atas yaitu punggung, leher, lengan/bahu, dan pergelangan tangan yang sering terjadi pada pekerja. Pada tahap pertama dalam proses analisa bagian tubuh yang mengalami sakit pada saat bekerja, dengan cara mengisi kuesioner untuk memberikan tanda ada tidaknya gangguan pada bagian area tubuh tersebut. Dari identifikasi yang dilakukan akan memberikan hasil yang dapat digunakan sebagai acuan untuk mengambil tindakan penangan yang tepat terhadap risiko ergonomi yang dialami pekerja, sehingga kinerja yang baik serta produktivitas yang tinggi dapat secara kontinu dicapai oleh pekerja tersebut.

Pada tahap selanjutnya yaitu Penentuan nilai exposure score dapat dilakukan dengan menggunakan exposure scoring sheet untuk menentukan skor pada tiap-tiap bagian tubuh. Exposure scoring sheet akan mengkombinasikan jawaban dari kuesioner operator dan kuesioner pengamat serta memberikan skor untuk masing-masing kombinasi yang terbentuk. Exposure score dihitung untuk masing-masing bagian tubuh seperti pada punggung, bahu atau lengan atas, pergelangan tangan, maupun leher. Contoh kombinasi yang terbentuk misalnya kombinasi antara postur dengan gaya atau beban, pergerakan dengan gaya atau beban, durasi dengan gaya atau beban, postur dengan durasi, atau pergerakan dengan durasi [1].

Selanjutnya tahap penentuan exposure level berdasarkan hasil perhitungan nilai dari exposure score, kemudian hasil dari perhitungan nilai exposure level untuk penentuan kategori resiko dan level tindakan selanjutnya [1].

Selanjutnya tahap usulan perbaikan perancangan fasilitas kerja dengan menggunakan analisa persentil yang didapatkan dari data anthopometri pekerja. Berdasarkan perhitungan kembali dari usulan tersebut diharapkan mendapat nilai exposure level dengan range 40\%. Nilai ini berarti stasiun kerja aman dan dapat menurunkan cidera musculocetal dan meningkatkan produktifitas kerja.

\section{HASIL DAN PEMBAHASAN}

Pada permasalahan yang menjadi latar belakang bahan penelitian adalah terjadinya keluhan pada cidera muscoluskeletal dari proses pengerjaan pembuatan produk sepatu bordir ini, yang beberapa tahapan kerja yang dilakukan secara berulang-ulang dan dalam jangka waktu yang lama. Dari pengawasan yang dilakukan pemilik UMKM didapatkan nilai dari stasiun kerja yang ada berada pada range 50-69\%, nilai ini menunjukkan perlu penelitian lebih lanjut dan perlu dilakukan usulan perbaikan perancangan fasilitas kerja.

Pada tahap pertama yaitu pengambilan data dengan kuesioner nordic body map yang digunakan untuk mengetahui ketidaknyamanan atau kesakitan pada tubuh. Pada penelitian ini kuesioner diberikan kepada 10 pekerja, yakni terhadap pekerja dibagian mesin plong, mesin pres, mesin jahit, pengamplasan, pengeleman dan mesin blendes. Berdasarkan data yang telah dikumpulkan melalui pengisian kuesioner Nordic Body Map yang diberikan kepada 10 pekerja di 6 stasiun kerja. Kemudian dari hasil yang telah didapat selanjutnya melakukan scoring terhadap individu dengan skala likert yang telah ditetapkan. Skala tersebut berupa keterangan yang ada didalam kuesioner yaitu TIDAK SAKIT (tidak merasakan gangguan pada bagian tertentu) dengan skor 1, AGAK SAKIT (merasakan sedikit gangguan atau rasa nyeri pada bagian tertentu) dengan skor 2, SAKIT ( merasakan ketidaknyamanan pada bagian tertentu) dengan skor 3, dan SANGAT SAKIT (merasakan ketidaknyamanan pada bagian tertentu) dengan skor 3, dan SANGAT SAKIT (merasakan ketidaknyamanan pada bagian tertentu dengan skala yang tinggi) dengan skor 4. Berikut merupakan kuesioner yang diberikan kepada pekerja, terlihat pada tabel 1 .

\footnotetext{
Analisa Resiko Postur Kerja Berdasarkan Hasil Evaluasi Menggunakan Metode Quick Exposure Check / Achmad Ganni Rizaldi, Atikha Sidhi Cahyana
}

Peer reviewed under responsibili of Universitas Muhammadiyah Sidoarjo.

(C) 2021 Universitas Muhammadiyah Sidoarjo. All Right reserved. This is an open access article under

the CC BY licence (http://creativecommons.org/licences/by/4.0/ ) 
Prozima, Vol. 5, No. 1, Juni 2021, 51-62

E. ISSN. 2541-5115

Journal Homepage: $h$ ttp://ojs.umsida.ac.id/index.php/prozima

DOI Link: http://doi.org/10.21070/prozima.v5i1.1350

Article DOI: http://doi.org/10.21070/prozima.v5i1.1350

Tabel 1 Kuesioner Nordic Body Map

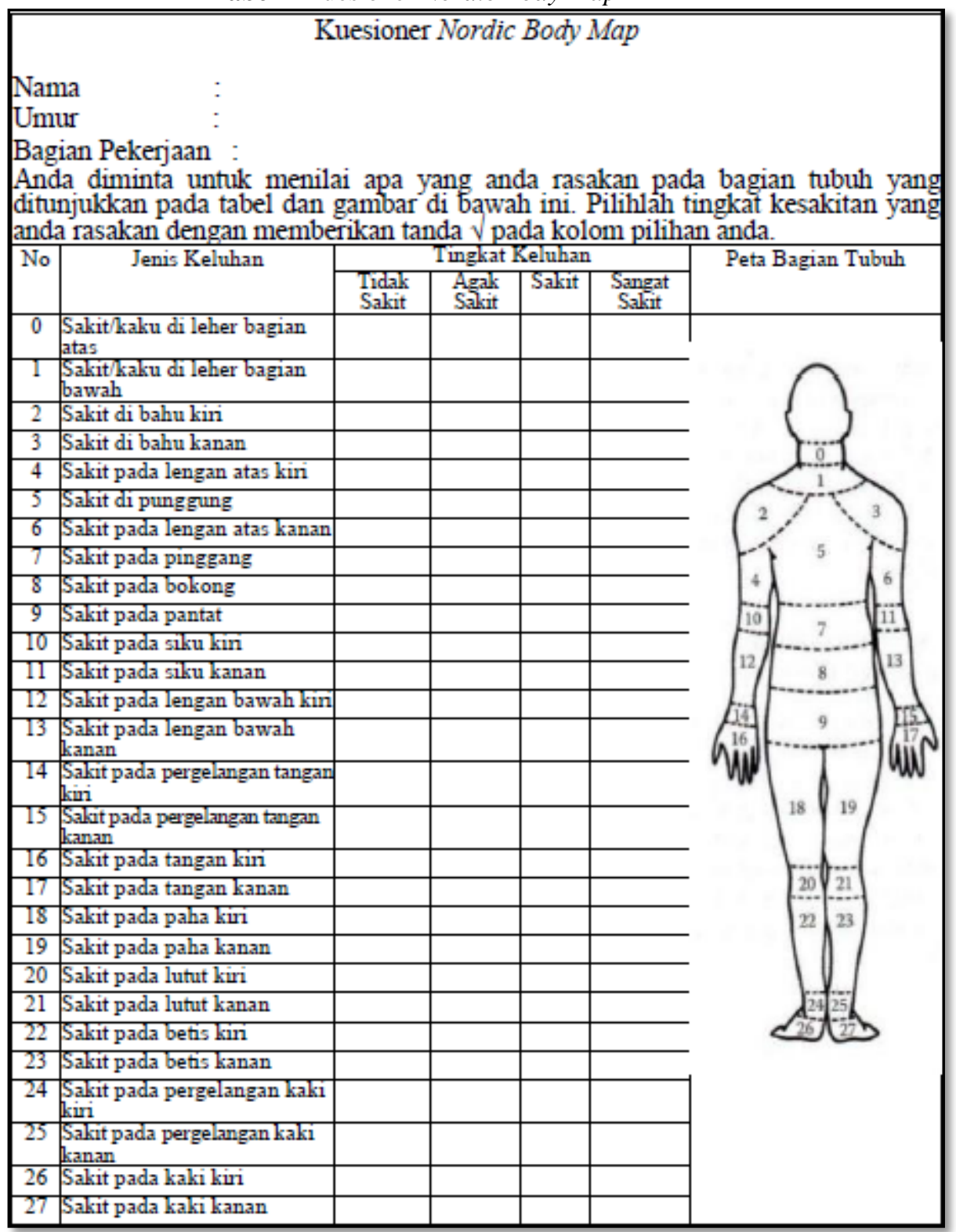

Analisa Resiko Postur Kerja Berdasarkan Hasil Evaluasi Menggunakan Metode Quick Exposure Check / Achmad Ganni Rizaldi, Atikha Sidhi Cahyana

Peer reviewed under responsibili of Universitas Muhammadiyah Sidoarjo.

(C) 2021 Universitas Muhammadiyah Sidoarjo. All Right reserved. This is an open access article under

the CC BY licence (http://creativecommons.org/licences/by/4.0/ ) 
Berdasarkan hasil dari tabel kuesioner diatas dapat diklasifikasikan tingkat resiko berdasarkan total skor individu pekerja dapat dililihat pada tabel 2.

Tabel 2 Klasifikasi Tingkat Resiko Berdasarkan Total Skor Individu

\begin{tabular}{|c|c|c|c|c|r|}
\hline No & Pekerja & $\begin{array}{c}\text { Total Skor } \\
\text { Individu }\end{array}$ & $\begin{array}{c}\text { Skala } \\
\text { Riket }\end{array}$ & $\begin{array}{c}\text { Tingkat } \\
\text { Resiko }\end{array}$ & Tindakan Perbaikan \\
\hline 1 & Pekerja 1 & 60 & 2 & Sedang & Mungkin diperlukan tindakan dikemudian hari \\
\hline 2 & Pekerja 2 & 62 & 2 & Sedang & Mungkin diperlukan tindakan dikemudian hari \\
\hline 3 & Pekerja 3 & 73 & 3 & Tinggi & Diperlukan tindakan segera \\
\hline 4 & Pekerja 4 & 58 & 2 & Sedang & Mungkin diperlukan tindakan dikemudian hari \\
\hline 5 & Pekerja 5 & 71 & 3 & Tinggi & Diperlukan tindakan segera \\
\hline 6 & Pekerja 6 & 64 & 2 & Sedang & Mungkin diperlukan tindakan dikemudian hari \\
\hline 7 & Pekerja 7 & 64 & 2 & Sedang & Mungkin diperlukan tindakan dikemudian hari \\
\hline 8 & Pekerja 8 & 65 & 2 & Sedang & Mungkin diperlukan tindakan dikemudian hari \\
\hline 9 & Pekerja 9 & 82 & 3 & Tinggi & Diperlukan tindakan segera \\
\hline 10 & Pekerja 10 & 71 & 3 & Tinggi & Diperlukan tindakan segera \\
\hline
\end{tabular}

Berdasarkan hasil data yang diolah dapat diketahui bahwa tingkat keluhan yang memiliki resiko terjadinya cidera tinggi dan memerlukan tindakan perbaikan segera yaitu pada pekerja 3 pada proses mesin press, pekerja 5 pada proses mesin jahit, pekerja 9 pada proses pengeleman, pekerja 10 pada proses mesin blendes. Dapat dilihat pada tabel 3 klasifikasi pekerja dengan resiko cidera tinggi.

Tabel 3 Klasifikasi Pekerja Dengan Resiko Cidera Tinggi

\begin{tabular}{|c|c|c|c|}
\hline No & Pekerja & Bagian Tubuh & Data Hasil \\
\hline 1 & Pekerja 2 & $\begin{array}{c}\text { Bahu kanan \& } \\
\text { lengan atas } \\
\text { kanan }\end{array}$ & $\begin{array}{l}\text { Terasa sakit pada saat penekanan pada saat proses mesin plong \& pegal } \\
\text { diakibatkan gerakan yang berulang-ulang dalam proses mesin plong }\end{array}$ \\
\hline 2 & Pekerja 3 & Punggung & Penggunaan otot punggung yang terlalu berat dalam bekerja \\
\hline 3 & Pekerja 4 & Pinggang & $\begin{array}{c}\text { Aktivitas berlebihan atau sering mengangkat dan duduk dalam posisi } \\
\text { yang tidak nyaman }\end{array}$ \\
\hline 4 & Pekerja 5 & Pantat & Posisi duduk yang tidak nyaman dan dalam waktu yang lama \\
\hline 5 & Pekerja 8 & $\begin{array}{l}\text { Punggung \& } \\
\text { pantat }\end{array}$ & $\begin{array}{l}\text { Penggunaan otot punggung yang terlalu berat dalam bekerja \& Posisi } \\
\text { duduk yang tidak nyaman dan dalam waktu yang lama }\end{array}$ \\
\hline 6 & Pekerja 9 & $\begin{array}{c}\text { Bahu kiri, } \\
\text { Paha kiri \& } \\
\text { kanan }\end{array}$ & $\begin{array}{l}\text { Terasa sakit pada saat penekanan pada saat proses pengeleman \& otot } \\
\text { paham kram disebabkan oleh terlalu banyak dipakai atau aktivitas }\end{array}$ \\
\hline 7 & Pekerja 10 & $\begin{array}{c}\text { Pergelangan } \\
\text { tangan kiri \& } \\
\text { kanan }\end{array}$ & Otot tegang dikarenakan pergerakan secara berlebihan \\
\hline
\end{tabular}

Tahap selanjutnya adalah memberi kuesioner quick exposure check yang mempertimbangkan kondisi yang dialami pekerja dari dua sudut pandang yaitu sudut pandang pengamat/observer dan operator/pekerja. Kuesioner QEC diberikan kepada seluruh operator pada stasiun kerja yang ada dan juga pengamat yang melihat bagaimana postur tubuh operator ketika bekeja. Kuesioner QEC untuk pengamat dan operator berbeda, akan tetapi keduanya digunakan untuk menganalisis kondisi pekerja. Kuesioner pengamat lebih menitik beratkan kepada postur tubuh yang terbentuk oleh operator ketika melakukan pekerjaannya. Kuesioner operator lebih menitik beratkan kepada yang dirasakan oleh operator ketika melakukan pekerjaannya seperti beban yang harus diangkat dan juga durasi kerja. Kuesioner pengamat dan operator seperti pada tabel 4 dan tabel 5.

\section{Analisa Resiko Postur Kerja Berdasarkan Hasil Evaluasi Menggunakan Metode Quick Exposure Check / Achmad Ganni Rizaldi, Atikha Sidhi Cahyana}

Peer reviewed under responsibili of Universitas Muhammadiyah Sidoarjo.

(C) 2021 Universitas Muhammadiyah Sidoarjo. All Right reserved. This is an open access article under the CC BY licence (http://creativecommons.org/licences/by/4.0/ ) 


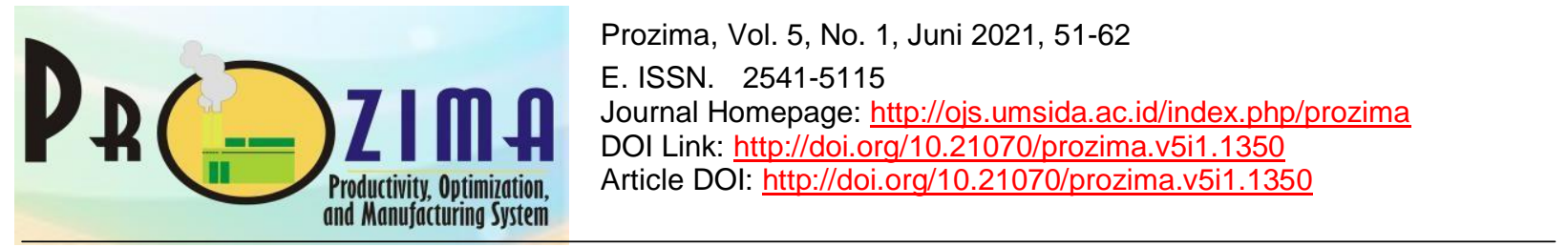

Tabel 4 Kuesioner Quick Exposure Check Pengamat

Nama Pekerja :

Tgl Pengamatan :

\section{KUESIONER PENGAMAT \\ Punggung}

A. Ketika melakukan pekerjaan, apakah punggung (pilih situasi terburuk)

A1. Hampir netral

A2. Agak memutar atau membungkuk

A3. Terlalu memutar atau membungkuk

.B. Pilih satu dari 2 pilihan pekerjaan :

Apakah

Untuk pekerjaan dengan duduk atau berdiri secara statis. Apakah punggung berada dalam posisi statis dalam waktu yang lama?

B1. Tidak

B2. Ya

Atau punggung?

Untuk pekerjaan mengangkat, mendorong/menarik. Apakah pergerakan pada

B3. Jarang (sek itar 3 kali per menit atau kurang) ?

B4. Sering (sekitar 8 kali per menit)?

B5. Sangat sering (sekitar 12 kali per menit atau lebih)?

\section{Bahu/Lengan}

C. Ketika pekerjaan dilakukan, apakah tangan (pilih situasi terburuk)

$\mathrm{C} 1$. Berada di sekitar pinggang atau lebih rendah?

C2. Berada di sekitar dada?

C3. Berada di sekitar bahu atau lebih tinggi?

D. Apakah pergerakan bahu/lengan

D1. Jarang (sebentar-sebentar)

D2.Sering (pergerakan biasa dengan berhenti sesaat/istirahat)

D3. Sangat sering (pergerakan yang hampir kontinyu) ?

\section{Pergelangan tangan/ Tangan}

E. Apakah pekerjaan dilakukan dengan (pilih situati terburuk)

E1. Pergelangan tangan yang hampir lurus ?

E2. Pergelangan tangan yang tertekuk ?

F. Apakah gerakan pekerjaan diulang

F1. 10 kali per menit atau kurang ?

F2. 11 hingga 20 kali per menit ?

Leher

F3. Lebih dari 20 kali per menit?

G. Ketika melakukan pekerjaan, apakah leher/kepala tertekuk atau berputar ?

G1. Tidak

G2. Ya, terkadang

G3. Ya, secara terus -menerus

Tahap pertama, pengembangan metode untuk merekam postur kerja untuk menghasilkan sebuah metode kerja yang cepat untuk digunakan tubuh dibagi dalam segmen-segmen yang membentuk tujuh kelompok atau grup yakni grup A, B, C, D, E, F dan G dari sudut pandang pengamat. Sedangkan untuk dari sudut pandang operator dibentuk kelompok atau grup yaitu grup H, I, J, K, L, M dan N. Hal ini untuk memastikan bahwa seluruh postur tubuh terekam, sehingga segala kejanggalan atau batasan postur oleh punggung atau leher yang mungkin saja mempengaruhi postur anggota tubuh atas dapat tercakup dalam penilaian.

Analisa Resiko Postur Kerja Berdasarkan Hasil Evaluasi Menggunakan Metode Quick Exposure Check / Achmad Ganni Rizaldi, Atikha Sidhi Cahyana

Peer reviewed under responsibili of Universitas Muhammadiyah Sidoarjo.

(C) 2021 Universitas Muhammadiyah Sidoarjo. All Right reserved. This is an open access article under

the CC BY licence (http://creativecommons.org/licences/by/4.0/ ) 
Tabel 5 Kuesioner Quick Exposure Check Operator

Nama Pekerja :

Jenis Pekeerjaan :

Tgl Pengamatan :

\section{KUESIONER OPERATOR}

H. Apakah berat maksimum yang diangkat secara manual oleh anda pada pekerjaan ini ?

H1. Ringan (sekitar 5kg atau kurang)

H2. Cukup berat (6 hingga 10kg)

H3. Berat (11 hingga 20kg)

H4 . Sangat Berat (lebih dari 20kg

I. Berapa lama rata -rata anda untuk menyelesaikan pekerjaan dalam sehari ?

I1. Kurang dari 2 jam

I2. 2 hingga 4 jam

I3. Lebih dari 4 jam

J. Ketika melakukan pekerjaan ini, berapa tingkat kekuatan yang digunakan oleh satu tangan?

J1. Rendah (kurang dari $1 \mathrm{~kg}$ )

J2. Sedang (1 hingga $4 \mathrm{~kg}$ )

J3. Tinggi (lebih dari $4 \mathrm{~kg}$ )

K. Apakah pekerjaan ini memerlukan penglihatan yang :

K1. Rendah (hamper tidk memerlukan untuk melihat secara detail)

K2. Tinggi (memerlukan untuk melihat secara detail)

L. Ketika bekerja apakah anda menggunakan kendaraan selama :

L1. Kurang dari 1 jam per hari atau tidak pernah ?

L2. Antara 1 hingga 4 jam per hari ?

L3. Lebih dari 4 jam per hari ?

M. Ketika bekerja apakah anda menggunakan alat yang menghasilkan getaran selama : M1. Kuraang dari 1 jam per hari atau tidak pernah ?

M2. Antara 1 hingga 4 jam per hari ?

M3. Lebih dari 4 jam per hari ?

N. Apakah anda mengalami kesulitan pada pekerjaan ini ?

N1. Tidak pernah

N2. Terkadang

N3. Sering

O. Pada umumnya, bagaimana anda menjalani pekerjaan ini ?

O1. Sama sekali tidak stress

O2. Cukup stress

O3. Stress

O4. Sangat stress

Tahap ke dua Pengembangan sistem skor untuk pengelompokkan bagian tubuh berdasarkan hasil dari penilaian grup A sampai grup $\mathrm{G}$ yang meliputi punggung, bahu, lengan, tangan, dan pergelangan tangan yang diamati dan ditentukan oleh skor masing-masing postur. Kemudian skor tersebut dimasukkan dalam tabel skor penilaian (Exposure Score) untuk memperoleh skor total. Dibawah ini adalah contoh tabel penilaian skor metode Quick Exposure Checklist (QEC). Tingkat risiko terjadinya cedera pada anggota tubuh berdasarkan dari nilai exposure score yang diperoleh kemudian disesuaikan dengan tabel untuk mengetahui risiko cidera pada masingmasing anggota tubuh. Selanjutnya tahap pengolahan data yang diperoleh dari hasil kuesioner pengamat/observer dan operator/pekerja dimasukkan kedalam lembar skor QEC, kemudian akan dihitung nilai exposure score pada

Analisa Resiko Postur Kerja Berdasarkan Hasil Evaluasi Menggunakan Metode Quick Exposure Check / Achmad Ganni Rizaldi, Atikha Sidhi Cahyana

Peer reviewed under responsibili of Universitas Muhammadiyah Sidoarjo.

(C) 2021 Universitas Muhammadiyah Sidoarjo. All Right reserved. This is an open access article under

the CC BY licence (http://creativecommons.org/licences/by/4.0/ ) 
Prozima, Vol. 5, No. 1, Juni 2021, 51-62

$\operatorname{PR} \bigcirc \underline{Z I M A}$

E. ISSN. 2541-5115

Journal Homepage: http://ojs.umsida.ac.id/index.php/prozima

DOI Link: http://doi.org/10.21070/prozima.v5i1.1350

Article DOI: http://doi.org/10.21070/prozima.v5i1.1350

4 bagian tubuh dari operator setiap stasiun kerja yang diteliti. Contoh perhitungan yang dilakukan pada lembar QEC seperti terlihat pada lampiran tabel 6 lembar skor quick exposure check mesin plong pekerja 1.

Analisa Resiko Postur Kerja Berdasarkan Hasil Evaluasi Menggunakan Metode Quick Exposure Check / Achmad Ganni Rizaldi, Atikha Sidhi Cahyana

Peer reviewed under responsibili of Universitas Muhammadiyah Sidoarjo.

(C) 2021 Universitas Muhammadiyah Sidoarjo. All Right reserved. This is an open access article under

the CC BY licence (http://creativecommons.org/licences/by/4.0/ ) 


\section{D.}

E. ISSN. 2541-5115

PROZIImA

Journal Homepage: http://ojs.umsida.ac.id/index.php/prozima

DOI Link: http://doi.org/10.21070/prozima.v5i1.1350

Productivity Optimization, Article DOI: http://doi.org/10.21070/prozima.v5i1.1350

Tabel 6 Lembar Quick Exposure Check Mesin Plong Pekerja

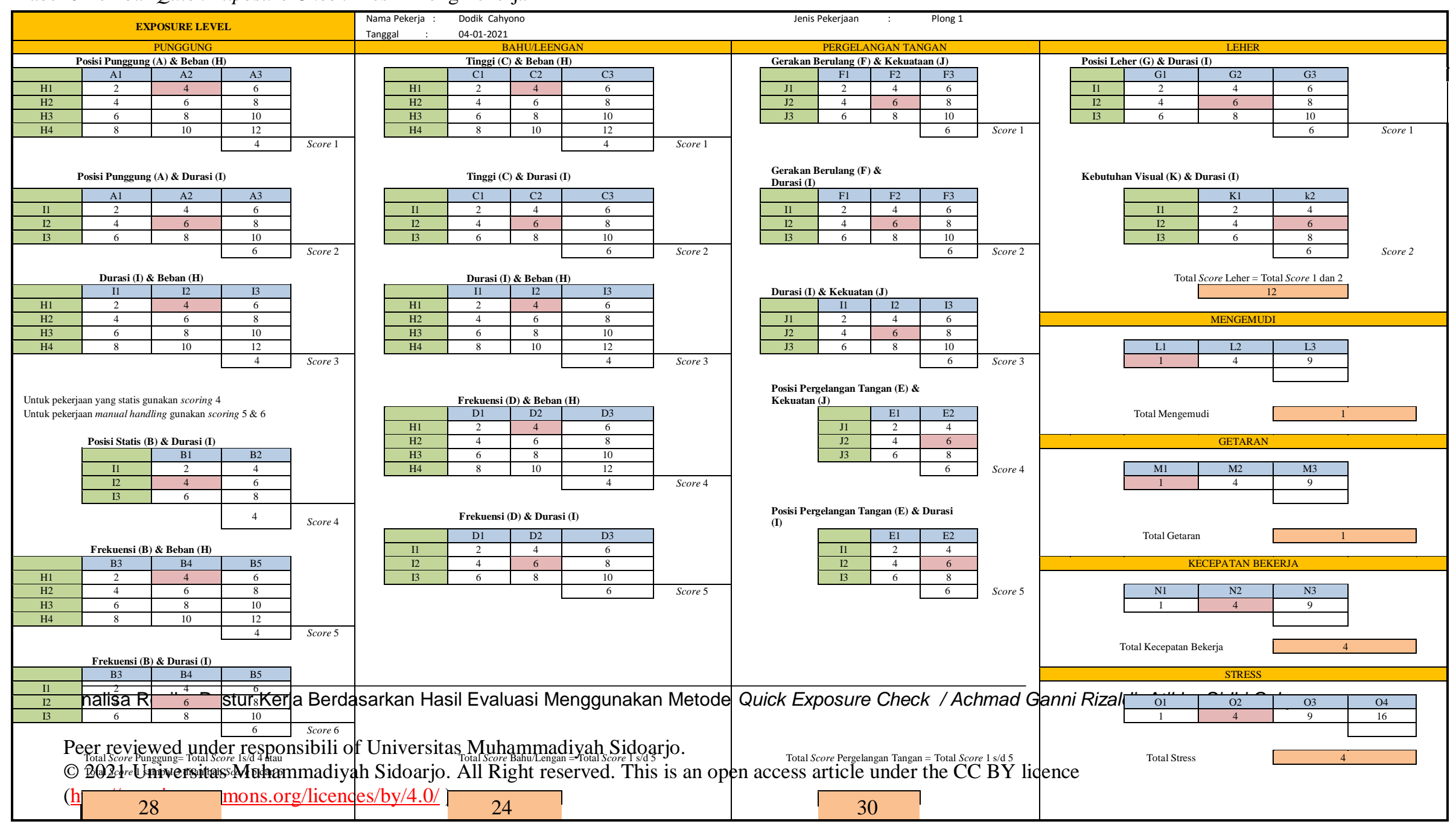




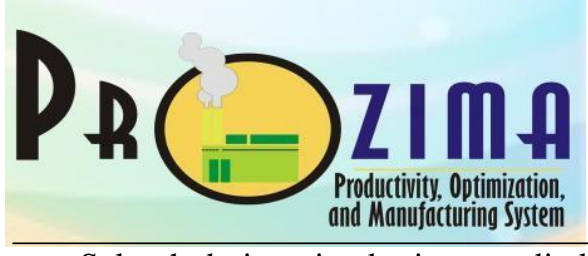

Prozima, Vol. 5, No. 1, Juni 2021, 51-62

E. ISSN. 2541-5115

Journal Homepage: http://ojs.umsida.ac.id/index.php/prozima

DOI Link: http://doi.org/10.21070/prozima.v5i1.1350

Article DOI: http://doi.org/10.21070/prozima.v5i1.1350

Seluruh dari stasiun kerja yang diteliti dilakukan perhitungan pada lembar skor skor quick exposure check tersebut. Kemudian hasil rekapitulasi dari hasil perhitungan exposure score dapat dilihat pada tabel.

Penentuan exposure level, berdasarkan hasil penghitungan nilai exposure score, maka dapat dilakukan perhitungan nilai exposure level dengan rumus :

$$
\mathrm{E}(\%)=\frac{\mathrm{X}}{\mathrm{x} \max } \mathrm{x} 100 \%
$$

Dimana:

$\mathrm{X}=$ Total skor yang didapat untuk paparan risiko cedera untuk punggung, bahu/lengan, pergelangan tangan, dan leher yang diperoleh dari perhitungan kuesioner.

Xmax $=$ Total maksimum skor untuk paparan yang mungkin terjadi untuk punggung, bahu/lengan, pergelangan tangan, dan leher.

Berikut hasil rekapitulasi dari perhitungan nilai exposure level setiap stasiun kerja beserta tindakan yang dilakukan. Dapat dilihat pada tabel 7.

Tabel 7 Hasil Rekapitulasi Nilai Exposure Level

\begin{tabular}{|c|l|c|c|}
\hline No & \multicolumn{1}{|c|}{ Stasiun Kerja } & $\begin{array}{c}\text { Exposure } \\
\text { Level (\%) }\end{array}$ & Tindakan \\
\hline 1 & Mesin plong (pekerja 1) & $59 \%$ & Perlu penelitian lebih lanjut dan dilakukan perubahan \\
\hline 2 & Mesin plong (pekerja 2) & $90 \%$ & Dilakukan penelitian dan perubahan secepatnya \\
\hline 3 & Mesin press (pekerja 1) & $65 \%$ & Perlu penelitian lebih lanjut dan dilakukan perubahan \\
\hline 4 & Mesin press (pekerja 2) & $82 \%$ & Dilakukan penelitian dan perubahan secepatnya \\
\hline 5 & Mesin jahit (pekerja 1) & $71 \%$ & Dilakukan penelitian dan perubahan secepatnya \\
\hline 6 & Mesin jahit (pekerja 2) & $78 \%$ & Dilakukan penelitian dan perubahan secepatnya \\
\hline 7 & Pengamplasan (pekerja 1) & $67 \%$ & Perlu penelitian lebih lanjut dan dilakukan perubahan \\
\hline 8 & Pengamplasan (pekerja 2) & $79 \%$ & Dilakukan penelitian dan perubahan secepatnya \\
\hline 9 & Pengeleman & $74 \%$ & Dilakukan penelitian dan perubahan secepatnya \\
\hline 10 & Mesin blendes & $78 \%$ & Dilakukan penelitian dan perubahan secepatnya \\
\hline
\end{tabular}

Selanjutnya tahap perancangan yang digunakan untuk merancang ulang fasilitas kerja dengan menggunakan pendekatan data antropometri. Nilai persentil yang sesuai stasiun kerja akan digunakan untuk merancang ulang fasilitas kerja. Berikut hasil pengolahan data anthopometri pekerja terlihat pada tabel 8 \& 9 .

Tabel 8 Nilai Kecukupan Data

\begin{tabular}{|c|c|c|c|c|c|c|c|c|}
\hline No & Data Anthopometri & $\mathrm{N}$ & $\mathrm{N}^{\prime}$ & Keterangan & $\begin{array}{c}\text { Rata- } \\
\text { Rata }\end{array}$ & BKA & BKB & Keterangan \\
\hline 1 & $\begin{array}{c}\text { Tinggi Badan } \\
\text { Tegak }\end{array}$ & 10 & 1.69 & Data Cukup & 165,41 & 176,81 & 154,01 & Data Seragam \\
\hline 2 & $\begin{array}{c}\text { Tinggi Bahu Posisi } \\
\text { Duduk }\end{array}$ & 10 & 3.2 & Data Cukup & 30,3 & 33,16 & 27,44 & Data Seragam \\
\hline 3 & Lebar Bahu & 10 & 2.49 & Data Cukup & 46,35 & 50,31 & 42,07 & Data Seragam \\
\hline 4 & Jangkauan Tangan & 10 & 6.6 & Data Cukup & 76,1 & 86,3 & 65,9 & Data Seragam \\
\hline 5 & Lebar Pinggul & 10 & 2.25 & Data Cukup & 30,85 & 33,29 & 28,41 & Data Seragam \\
\hline 6 & $\begin{array}{c}\text { Tinggi Siku Tegak } \\
\text { Lurus }\end{array}$ & 10 & 1.16 & Data Cukup & 89,1 & 94,2 & 84 & Data Seragam \\
\hline
\end{tabular}

\section{Analisa Resiko Postur Kerja Berdasarkan Hasil Evaluasi Menggunakan Metode Quick Exposure Check / Achmad Ganni Rizaldi, Atikha Sidhi Cahyana}

Peer reviewed under responsibili of Universitas Muhammadiyah Sidoarjo.

(C) 2021 Universitas Muhammadiyah Sidoarjo. All Right reserved. This is an open access article under

the CC BY licence (http://creativecommons.org/licences/by/4.0/ ) 


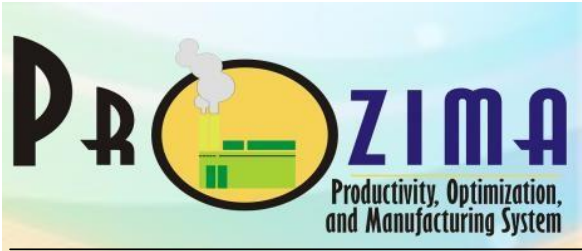

Prozima, Vol. 5, No. 1, Juni 2021, 51-62

E. ISSN. 2541-5115

Journal Homepage: http://ojs.umsida.ac.id/index.php/prozima

DOI Link: http://doi.org/10.21070/prozima.v5i1.1350

Article DOI: http://doi.org/10.21070/prozima.v5i1.1350

Tabel 9 Nilai Persentil

\begin{tabular}{|c|l|c|c|c|}
\hline No & \multicolumn{1}{|c|}{ Data Anthopometri } & Persentil 5 & Persentil 50 & Persentil 95 \\
\hline 1 & Tinggi Badan Tegak & 156,04 & 165,41 & 174,78 \\
\hline 2 & Tinggi Bahu Posisi Duduk & 28 & 30,3 & 32,6 \\
\hline 3 & Lebar Bahu & 43,28 & 46,65 & 48,38 \\
\hline 4 & Jangkauan Tangan & 67,72 & 76,1 & 84,48 \\
\hline 5 & Lebar Pinggul & 28,84 & 30,85 & 32,85 \\
\hline 6 & Tinggi Siku Tegak Lurus & 84,91 & 89,1 & 93,29 \\
\hline
\end{tabular}

Tahap selanjutnya adalah usulan perbaikan perancangan fasilitas kerja, Berikut merupakan usulan rancangan fasilitas kerja UMKM XYZ pada stasiun kerja mesin plong dan mesin press dengan menggunakan analisa persentil yang didapatkan dari data anthopometri pekerja, usulan perbaikan fasilitas kerja mesin plong dan mesin press terlihat pada tabel $10 \& 11$.

Tabel 10 Usulan Perbaikan Rancangan Fasilitas Kerja Mesin Plong

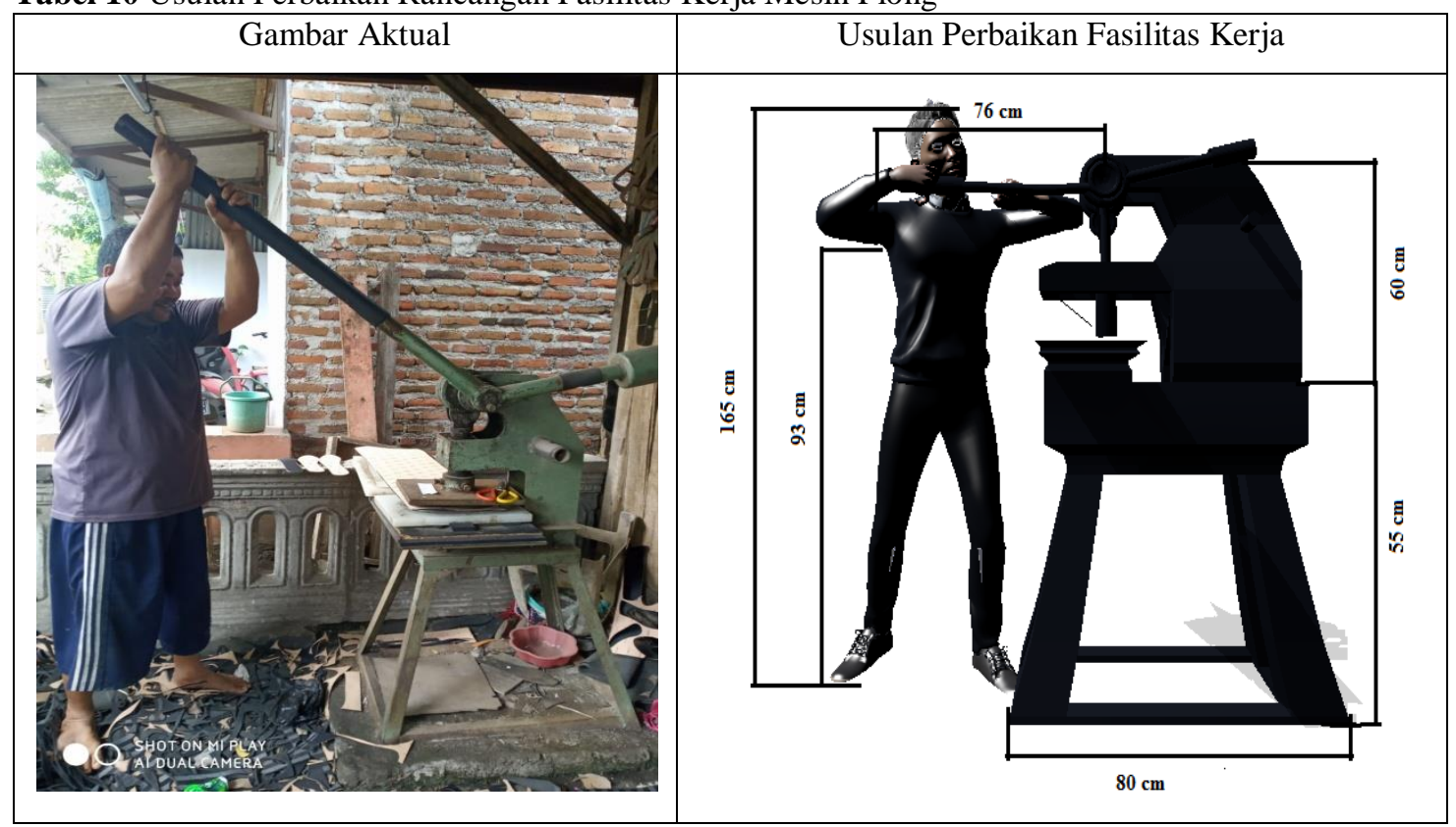

Untuk menentukan tinggi badan pekerja proses mesin plong, persentil yang digunakan adalah persentil $5 \mathrm{o}^{\text {th }}$ dengan ukuran tinggi sebesar $165 \mathrm{~cm}$ yang bertujuan agar pekerja yang memiliki postur tubuh rendah maupun tinggi dapat menggunakan fasilitas kerja. Untuk menentukan jangkauan tangan pada objek kerja didapatkan persentil $5 \mathrm{o}^{\text {th }}$ dengan ukuran sebesar $76 \mathrm{~cm}$ dan lebar dudukan mesin sebesar $80 \mathrm{~cm}$. Pada Tinggi Siku Tegak Lurus persentil yang digunakan adalah $95^{\text {th }}$ dengan ukuran tinggi sebesar $93 \mathrm{~cm}$, untuk tangan lurus menggapai objek benda kerja. Sehingga didapatkan untuk ukuran dudukan mesin menggunakan tinggi sebesar $55 \mathrm{~cm}$ dan dengan tinggi mesin sebesar $60 \mathrm{~cm}$.

Analisa Resiko Postur Kerja Berdasarkan Hasil Evaluasi Menggunakan Metode Quick Exposure Check / Achmad Ganni Rizaldi, Atikha Sidhi Cahyana

Peer reviewed under responsibili of Universitas Muhammadiyah Sidoarjo.

(C) 2021 Universitas Muhammadiyah Sidoarjo. All Right reserved. This is an open access article under the CC BY licence (http://creativecommons.org/licences/by/4.0/ ) 
Tabel 11 Usulan Perbaikan Rancangan Fasilitas Kerja Mesin press

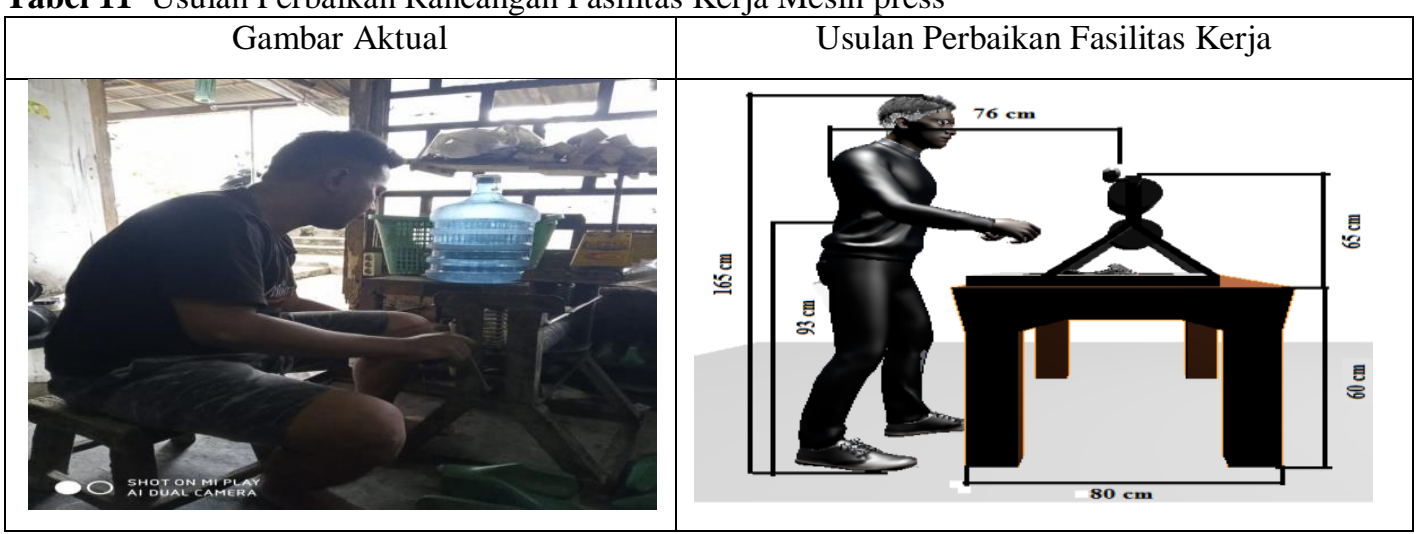

Pada pengoperasian mesin press ini, posisi kerja dirubah dari posisi duduk menjadi posisi berdiri. Posisi ini diharapkan untuk mempercepat proses pekerjaan karena pekerja lebih leluasa bekerja untuk posisi kerja berdiri tegak. Untuk menentukan tinggi badan pekerja, persentil yang digunakan adalah persentil $5 o^{\text {th }}$ dengan ukuran $165 \mathrm{~cm}$ yang bertujuan agar pekerja yang memiliki postur tubuh rendah maupun tinggi dapat menggunakan fasilitas kerja. Untuk menentukan jangkauan tangan pada objek kerja didapatkan persentil $5 \mathrm{o}^{\text {th }}$ dengan ukuran jangkauan tangan sebesar $76 \mathrm{~cm}$ dan lebar dudukan mesin sebesar $80 \mathrm{~cm}$. Pada Tinggi Siku Tegak Lurus persentil yang digunakan adalah $95^{\text {th }}$ dengan ukuran tinggi sebesar $93 \mathrm{~cm}$, untuk tangan lurus menggapai objek benda kerja. Sehingga didapatkan untuk ukuran dudukan mesin menggunakan tinggi $60 \mathrm{~cm}$ dan dengan tinggi mesin $65 \mathrm{~cm}$.

\section{KESIMPULAN}

Berikut hasil dari perhitungan nilai exposure level setiap stasiun kerja beserta tindakan yang dilakukan. Stasiun kerja mesin plong pekerja 1 mendapat nilai 59\% dengan tindakan perlu penelitian lebih lanjut dan dilakukan perubahan, sedangkan pekerja 2 mendapat nilai $90 \%$ dengan tindakan dilakukannya penelitian dan perubahan secepatnya. Stasiun kerja mesin press pekerja 1 mendapat nilai $65 \%$ dengan tindakan perlu penelitian lebih lanjut dan dilakukan perubahan, sedangkan pekerja 2 mendapat nilai 82\% dengan tindakan dilakukannya penelitian dan perubahan secepatnya. Stasiun kerja mesin jahit pekerja 1 mendapat nilai $71 \%$, sedangkan pekerja 2 mendapat nilai $78 \%$ keduanya dilakukan tindakan penelitian dan perubahan secepatnya. Stasiun kerja pengamplasan pekerja 1 mendapat nilai $67 \%$ dengan tindakan perlu penelitian lebih lanjut dan dilakukan perubahan, sedangkan pekerja 2 mendapat nilai $79 \%$ dengan tindakan dilakukannya penelitian dan perubahan secepatnya. Stasiun kerja mesin blendes mendapat nilai $74 \%$ dengan tindakan dilakukannya penelitian dan perubahan secepatnya. Stasiun kerja pengeleman mendapat nilai $78 \%$ dengan tindakan dilakukannya penelitian dan perubahan secepatnya. Usulan perbaikan sistem kerja di UMKM XYZ adalah dengan menyediakan fasilitas kerja kursi, meja dan alat bantu dudukan mesin yang sesuai dengan data anthropometri pekerja pada posisi pekerja sedang duduk maupun posisi berdiri, seperti tabel 4. Berdasarkan perhitungan kembali dari usulan tersebut diharapkan mendapat nilai exposure level dengan range 40\%. Nilai ini berarti stasiun kerja aman dan dapat menurunkan cidera musculocetal dan meningkatkan produktivitas pekerja.

\section{DAFTAR PUSTAKA}

[1] Sari, Fita Permata. dkk. (2017). Penilaian Postur Kerja Di Area Konstruksi CV.Valasindo Dengan Metode Quick Exposure Check. Vol. 16, No.2: hal 107-113.

[2]. Adha, Ezi Rezia. dkk. (2014). Usulan Perbaikan Stasiun Kerja Pada PT. Sinar Advertama Servicindo (SAS) Berdasarkan Hasil Evaluasi Menggunakan Metode Quick Exposure Check (QEC). Jurnal Institut Teknologi Nasional. Vol. 02, No. 04, hal 108-120.

[3]. Erlangga, Djodi \& Nurfajriah. (2019). Usulan Perancangan Kabin Masinis Krl Commuter Line Yang Ergonomis Menggunakan Model Virtual Enviroment. Vol. 04, No. 02, September 2019. hal

Analisa Resiko Postur Kerja Berdasarkan Hasil Evaluasi Menggunakan Metode Quick Exposure Check / Achmad Ganni Rizaldi, Atikha Sidhi Cahyana

Peer reviewed under responsibili of Universitas Muhammadiyah Sidoarjo.

(C) 2021 Universitas Muhammadiyah Sidoarjo. All Right reserved. This is an open access article under the CC BY licence (http://creativecommons.org/licences/by/4.0/ ) 
Prozima, Vol. 5, No. 1, Juni 2021, 51-62

E. ISSN. 2541-5115

Journal Homepage: http://ojs.umsida.ac.id/index.php/prozima

DOI Link: http://doi.org/10.21070/prozima.v5i1.1350

Article DOI: http://doi.org/10.21070/prozima.v5i1.1350

$25-32$.

[4]. Dewi, Luciana Triani. (2016). Karakterisasi Keluhan Muskuloskeletal Akibat Postur Kerja Buruk Pada Pekerja Industri Kecil Makanan. Jurnal Ilmiah Teknik Industri. Vol. 15, No. 02, Des 2016. hal 145-150. 